\title{
PENINGKATAN PEMAHAMAN MATEMATIS GURU MA PERSIS DALAM MENYELESAIKAN MASALAH ILMU FALAK
}

\author{
Rahayu Kariadinata ${ }^{1)}$, Ida Nuraida ${ }^{2)}$ \\ ${ }^{1)}$ Program Studi Pendidikan Matematika, Fakultas Tarbiyah dan Keguruan, UIN Sunan Gunung Djati Bandung, \\ rahayu.kariadinata@uinsgd.ac.id \\ 2) Program Studi Pendidikan Matematika, Fakultas Tarbiyah dan Keguruan, UIN Sunan Gunung Djati Bandung, \\ idanuraida@uinsgd.ac.if
}

\begin{abstract}
Abstrak
Guru Madrasah Aliah (MA) Persatuan Islam (PERSIS) mengalami kesulitan dalam memahami perhitungan matematika dalam ilmu Falak khususnya terait masalah dalam menentukan arah kiblat, sehingga sangat dibutuhkan suatu program yang dapat membantu pemahaman guruguru tersebut. Program Pengabdian kepada Masyarakat (PkM) UIN Sunan Gunung Djati Bandung menyelenggarakan suatu program dengan tujuan mengatasi kesulitan guru-guru dalam memahami konsep-konsep matematika untuk menyelesaikan masalah Ilmu Falak di Madrasah Aliah PERSIS di Jawa Barat. Metode yang digunakan adalah CBR (Community Based Research). Kegiatan PkM ini diikuti oleh 50 orang guru dan melibatkan steakholder yang ada di Pimpinan Pusat (PP) PERSIS. Hasil evaluasi menunjukkan PkM dapat meningkatkan pemahaman matematis guru-guru MA PERSIS dalam menyelesaikan masalah terkait Ilmu Falak khususnya menentukan arah kiblat.
\end{abstract}

Kata Kunci: arah kiblat, community based research, falak

\begin{abstract}
Teachers of Madrasah Aliah (MA) PERSIS have difficulty in understanding mathematical calculations in Ilmu Falak, especially related to problems in determining the direction of Qibla, so it is needed a program that can help the understanding of these teachers. The Community Service Program of UIN Sunan Gunung Djati Bandung held a program with the aim of overcoming the difficulties of teachers in understanding mathematical concepts to solve the problem of Ilmu Falak in the Islamic School of PERSIS in West Java. The method used is CBR (Community Based Research). This PkM activity was attended by 50 teachers and involved steakholders in the Pimpinan Pusat (PP) PERSIS. Evaluation results show that Program can improve the mathematical understanding of MA PERSIS teachers in solving problems related to Ilmu Falak, especially in determining the Qibla direction.
\end{abstract}

Keywords: qibla direction, community based research, falak

\section{PENDAHULUAN}

Perkembangan matematika di dunia Islam bermula dari kebudayaan Babilonia, Mesir, India dan Persia. Matematika berkembang di kebudayaan Yunani yang dikembangkan oleh para filosuf dan ilmuwan Yunani. Kaum muslimin yang kemudian memelihara dan mengembangkan melalui penelitian dan eksperimen (Muhtar 2014). Dunia Islam mempunyai khasanah sains dan matematika yang berkembang sangat pesat pada masanya. Sumbangsih pemikiran ilmuwan Muslim terhadap perkembangan sains dan matematika tidak bisa dianggap kecil (Aji 2014). Katakanlah seorang ilmuwan terkenal Al-Kawarizmi, kontribusinya dalam matematika sudah tidak diragukan lagi. AlKhawarizmi menerbitkan buku yang paling populer yaitu, al-Jabar wa al-Muqabalah (aljabar dan 
persamaan)(Huda and Mutia 2017). Buku ini diterbitkan di London pada tahun 1831 dan di New York pada tahun 1945 dan sangat terkenal di timur dan barat, ditulis dalam bahasa Arab pada tahun 830 H.(Baki 1992)

Perkembangan matematika dalam Islam tak terlepas Alquran dan Sunnah yang merupakan pedoman bagi umat Islam dalam menjalankan Syariat Islam (Muniri 2016). Kebutuhan matematika dalam pelaksanaan syariat Islam dapat dilihat dari beberapa syariat yang membutuhkan matematika seperti menetapkan waktu salat, arah kiblat, menentukan zakat yang harus dikeluarkan, waktu haji, dan waktu gerhana untuk melaksanakan salat gerhana, penetapan awal waktu shaum Ramadhan dan hari raya Idul Fitri dan Idul Adha, ilmu waris (fara'id) dll. Oleh karena itu karena kalkulasi matematika banyak digunakan dalam pelaksanaan syariat Islam, maka beberapa konsep yang terkait dengannya kami sebut sebagai Matematika Islam. Salah satu ilmu yang melibatkan perhitungan matematika dalam beberapa syariat Islam sering disebut sebagai Ilmu Falak.

Ilmu Falak adalah ilmu yang mempelajari lintasan benda langit, khususnya bumi, bulan dan matahari. Hal ini digunakan oleh umat Islam untuk menentukan hal-hal yang berkaitan dengan ibadah mahdhoh (Marpaung 2015). Diantara yang dipelajari dalam Ilmu Falak adalah menentukan arah kiblat, menentukan awal waktu shalat, menentukan awal bulan hijriah, gerhana matahari, gerhana bulan dll.

Pada awal abad $20 \mathrm{M}$ ilmu Falak mulai tumbuh dan berkembang di Indonesia. Para ulama muda yang kembali dari bermukim di Mekkah mereka tidak hanya membawa catatan-catatan ilmu tentang tafsir, hadis, fiqih, dan tasawuf, melainkan juga membawa catatan-catatan Ilmu Falak yang mereka dapatkan di Mekkah sewaktu mereka belajar di sana yang kemudian mereka ajarkan kepada para santrisantrinya di Indonesia (Alimuddin 2016). Akhirnya, Ilmu Falak berkembang dari waktu ke waktu karena terus menerus diajarkan di pondok-pondok pesantren maupun lembaga pendidikan formal.

PERSIS adalah salah satu lembaga ormas Islam memiliki fokus perhatian yang dalam terhadap ilmu Falak. Sudah banyak para ahli Falak yang bermunculan dari pesantren-pesantren PERSIS dan berkontribusi besar pada dinamika ilmu Falak di
Indonesia. Salahsatu ulama yang terkenal di PERSIS adalah KH Ali Ghazaly (Nashrullah 2014), hasil karyanya yang fenomenal adalah kalender hijriah, di dalamnya juga memuat waktu-waktu shalat, waktu syuruq (terbit matahari), dan gerhana.

Sebagai salah satu upaya untuk melestarikan khasanah keilmuan Falak ini, maka PERSIS memasukkan ilmu Falak dalam kurikulum pendidikannya. Ilmu Falak diajarkan di jenjang Madrasah Aliah atau yang terkenal di kalangan PERSIS dengan sebutan Mu'alimin.

Ilmu Falak telah diajarkan di pesantren PERSIS sudah sejak lama, sudah menjadi keniscayaan bahwa ilmu Falak harus terus diajarkan dari generasi ke genarasi agar kemanfaatannya dapat terus berlanjut. Ilmu Falak diajarkan di pesantren PERSIS khususnya di Madrasah Aliah Mu'alimin oleh guru-guru dengan corak dan latar belakang keilmuan yang beragam. Pengajar ilmu Falak selayaknya memiliki latar belakang pendidikan Ilmu Falak, akan tetapi fakta lapangan guru-guru yang mengajar ilmu Falak memiliki corak keilmuan yang berbeda-beda bahkan tidak sesuai dengan bidang keahliannya. Hal ini mengakibatkan guru-guru memerlukan pengetahuan tambahan sebagai bekal dalam mengajarkan ilmu Falak, di antaranya adalah bekal pengetahuan matematika sebagai penunjang signifikan dalam perhitungan konsep-konsep astronomi dalam Ilmu Falak.

Beberapa penelitian yang dilakukan sebelumnya yaitu dilakukan oleh (Syukur 2010) mengemukakan pembelajaran dengan menggunakan metode hisab praktis di Madrasah Aliah terbukti efektif dalam pembelajaran ilmu Falak. Kemudian (Fatwa and Hamdani 2016) mengembangkan model pembelajaran Ilmu Falak yang efektif dan dapat diterapkan di masyarakat, salah satunya adalah dengan menggunakan Contectual Teaching and Learning (CTL). Selain itu dikemukakan juga bahwa pemahaman yang baik terhadap kemampuan matematik dapat meningkatkan kemampuan dalam memahami ilmu Falak, hal ini sejalan dengan penelitian yang dilakukan oleh (Syaripudin 2007).

Oleh karenanya Universitas Islam Negeri (UIN) Sunan Gunung Djati Bandung sebagai institusi Perguruan Tinggi memiliki tugas yang dikenal dengan Tri Darma Perguruan Tinggi, yaitu pendidikan, penelitian dan pengabdian. Salah 
satunya adalah melalui kegiatan Pengabdian kepada Masyarakat (PkM), Program PkM yang dimaksud dilakukan pada komunitas guru-guru Ilmu Falak di lingkungan lembaga PERSIS Setelah mengikuti program ini, guru-guru diharapkan memiliki pemahaman yang baik dalam beberapa konsep matematika. Pemahaman yang baik ini akan menjadikan mereka menjadi guru-guru yang berdaya dan memiliki kemampuan dalam menyelesaikan permasalahan terkait Ilmu Falak dalam proses pembelajaran di kelas. Jika guru-guru telah memiliki pemahaman yang baik, maka diharapkan mampu menularkan pemahaman akan Ilmu Falak ini kepada murid-muridnya, sehingga estafeta Ilmu Falak ini akan terus berlanjut pada generasi-generasi yang akan datang.

Rumusan masalah dari program pengabdian ini adalah :

1. Kesulitan-kesuliatan apa yang dialami guruguru dalam memahami konsep-konsep matematika yang terdapat dalam mata pelajaran Ilmu Falak pada madrasah Aliah PERSIS di Jawa Barat?.

2. Apakah program pelatihan dapat membantu guru-guru dalam memahami konsep-konsep matematika yang terdapat dalam mata pelajaran Ilmu Falak pada madrasah Aliah PERSIS di Jawa Barat?.

Tujuan dari program Pengabdian kepada Masyarakat $(\mathrm{PkM})$ berbasis riset ini adalah untuk mengetahui kesulitan guru-guru dalam memahami konsep-konsep matematika yang terdapat dalam mata pelajaran Ilmu Falak pada madrasah Aliah PERSIS di Jawa Barat. Selain itu tujuan dari PkM berbasis riset ini adalah mengatasi kesulitan guruguru akan konsep-konsep matematika pada mata mata pelajaran Ilmu Falak pada madrasah Aliah PERSIS di Jawa Barat.

Manfaat dari program PkM yang akan dilaksanakan adalah guru-guru Ilmu Falak yang tidak memiliki latar belakang ilmu falak maupun latar belakang matematika dapat memahami konsepkonsep yang digunakan dalam Ilmu Falak dengan baik. Selain itu, bagi steakholder dapat menggunakan rekomendasi-rekomendai hasil kegiatan PkM berbasis riset ini sebagai bahan dalam mengeluarkan kebijakan-kebijakan pendidikan di lingkungan PERSIS.

\section{METODOLOGI PENGABDIAN}

Program pengabdian menggunakan metode CBR (Community Based Research). CBR didefinisikan sebagai model penelitian transformatif yang diselenggarakan berdasarkan prinsip-prinsip pemberdayaan masyarakat, kolaborasi, dan perubahan sosial yang menempatkan masyarakat yang peduli berperan serta bukan sebagai subyek penelitian tetapi sebagai mitra kerja sama dan agen perubahan (Hanafi 2015).

Joanna Ochocka dari Center for CommunityBased Research membagi tahapan CBR menjadi 4 yaitu: peletakan dasar (laying the foundation), perencanaan penelitian (research planning), pengumpulan dan analisis data (information gathering and analysis) dan aksi atas temuan (acting on findings) (Hanafi 2015). Tahapan CBR ini dapat dilihat pada gambar 1 berikut.

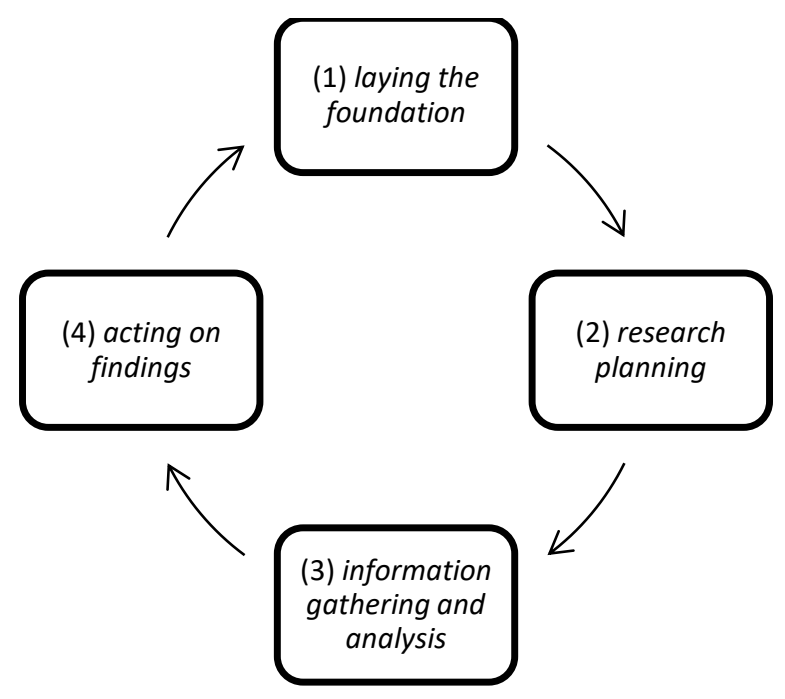

Gambar 1 : Langkah-langkah CBR

\section{PELAKSANAAN KEGIATAN}

Kegitan PkM yang dilaksanakan melibatkan stakeholders yang ada di komunitas yaitu lembaga Persatuan Islam (PERSIS), steakholder yang terlibat diantaranya adalah Bidang Tarbiyah dan Dewan Hisab Rukyat. Pelibatan steakholder dimaksudkan agar kegiatan bersinergi dan melibatkan potensipotensi yang ada di lembaga mitra. Kegiatan pada 
tahap ini adalah melakukan diskusi terkait latar belakang dan tujuan PkM yang akan dilaksanakan.

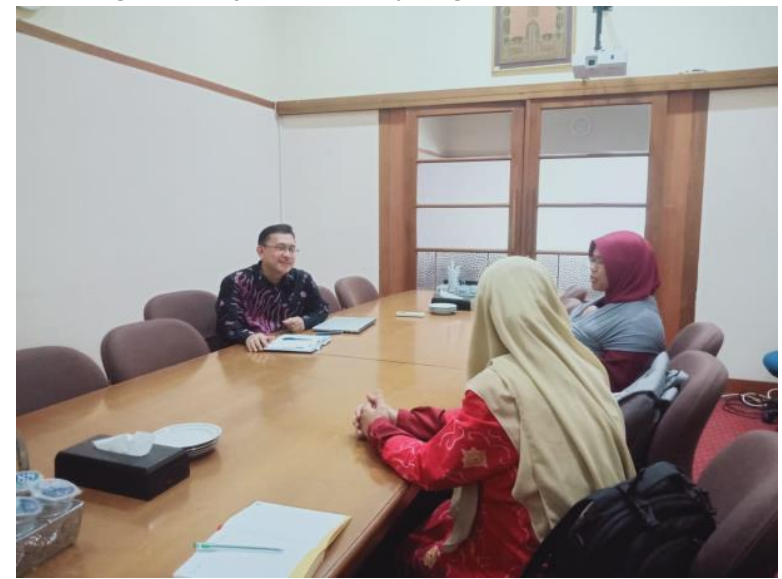

Gambar 2. Kegiatan diskusi dengan Steakholder

Kegiatan selanjutnya adalah melakukan perencanaan kegiatan. Perencanan kegiatan dilakukan dengan melakukan pembagian peran masing-masing, baik peran sebagai pemberi materi kegiatan maupun pelaksana teknis kegiatan.

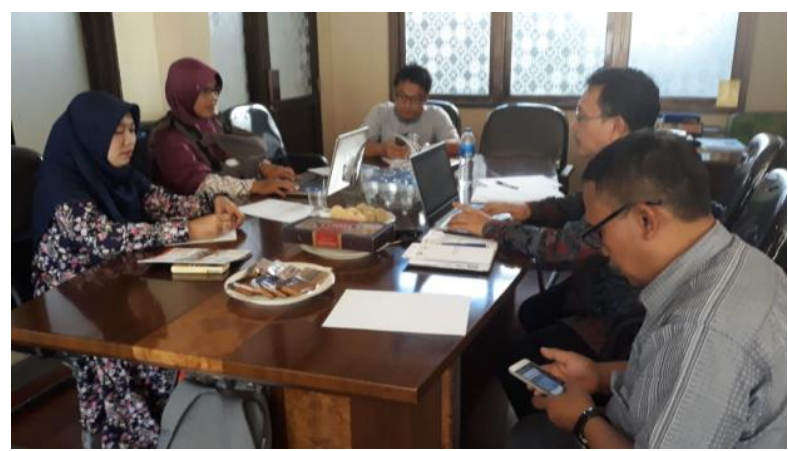

Gambar 3. Rapat bersama Steakholder

Pelaksana teknis kegiatan dibantu oleh mahasiswa, mahasiswa berperan dalam menyiapkan segala kebutuhan teknis terkait pelaksanaan kegiatan PkM.

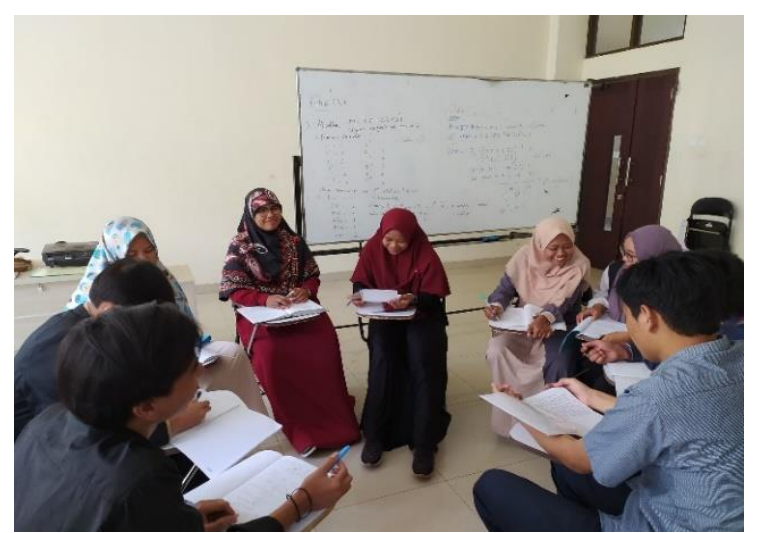

Gambar 4. Rapat bersama Tim Mahasiswa
Kegiatan pengabdian kepada masyarakat diikuti oleh guru-guru dari MA PERSIS yang ada di Jawa Barat yang berjumlah sebanyak 50 orang.

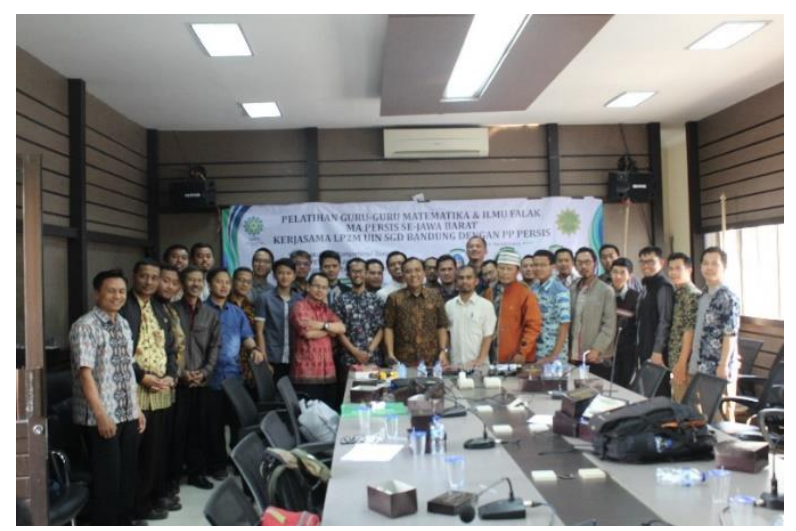

Gambar 5. Peserta Pelatihan

Pembicara dari tim pengabdi, yaitu Prof. Dr. Hj. Rahayu Kariadinata, M.Pd menyampaikan materi tentang "Trigonometri dalam Perhitungan Arah Kiblat". Pada materi ini dijelaskan bagaimana trigonometri, terutama trigonometri pada segitiga bola.

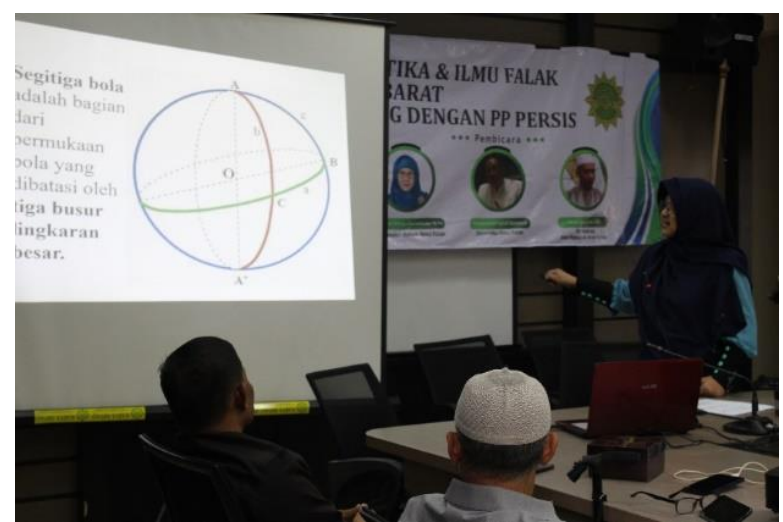

Gambar 5. Materi "Trigonometri dalam Perhitungan Arah Kiblat"

Selanjutnya, adalah KH. Muhammad Iqbal Santoso (Ketua Dewan Hisab Rukyat PP PERSIS) menyampaikan materi tentang "Dinamika Ilmu Falak". Pada materi ini dijelaskan tentang makna ilmu Falak dan dinamika pembelajaran ilmu Falak di MA PERSIS.

Konsep matematika yang terkait dengan syariat islam, antara lain: zakat, warist, asuransi, ekonomi Islam, dll. Dalam kajian Fiqih Ilmu Hisab mencakup Hisab Falak dan Hisab Faraidl. Umumnya Ilmu Falak 
mempelajari arah kiblat, waktu-waktu sholat, awal bulan hijriyyah dan gerhana matahari dan bulan.

Pengajaran Ilmu Falak memadukan antara teori, komputasi dan observasi. Ilmu Falak juga beririsan dengan ilmu lainnya, misalnya, Atronomi, Astrofisika, aplikasi statistik, komputasi ilmu falak, astronomi komputasi, Meteorologi, Geofisika, dsb. Ilmu falak membutuhkan dasar-dasar matematika seperti: aritmetika, statistika, geometri Ruang, Geometri Bola, Trigonometri Bidang Datar, Trigonometri Bola (spherical trigonometri), dll.

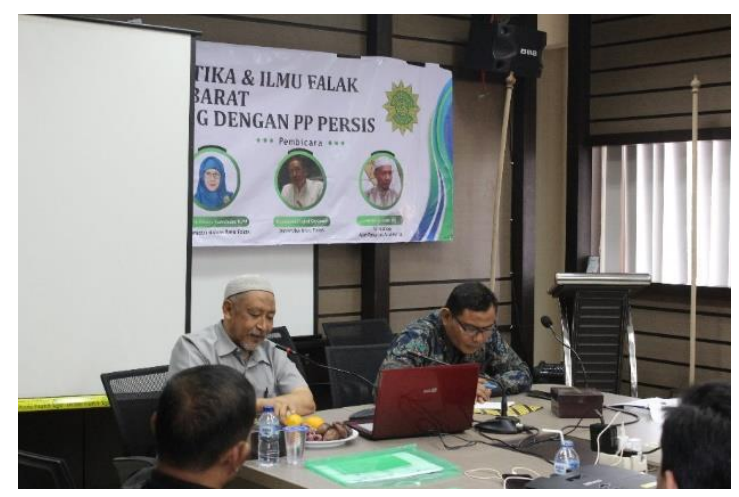

Gambar 6. Materi “Dinamika Ilmu Falak”

Terakhir, materi "Alat Penentuan Arah Kiblat" oleh Hendro Styanto, M.Si, peneliti dan pemilik Imah Noong. Pada materi ini dijelaskan tentang alat untuk mengukur arah kiblat, yang dinamakan Mizwala Qibla Finder (Sundial Pengukur Arah Kiblat). Alat ini menggunakan prinsip-prinsip trigonometri pada segitiga bola.

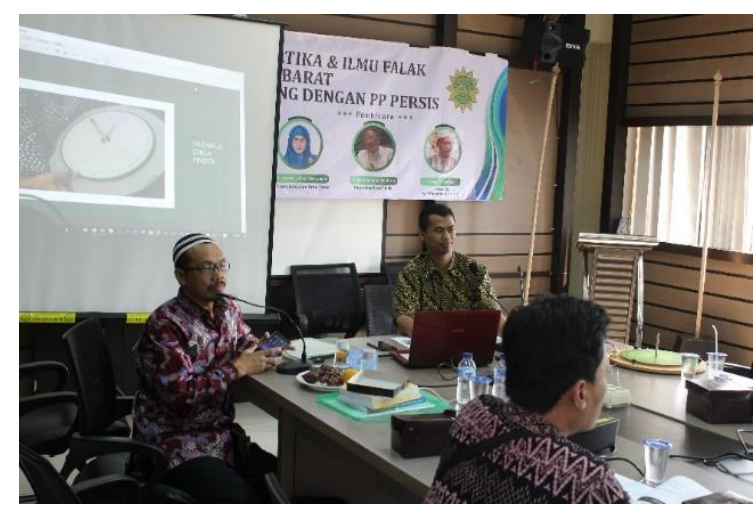

Gambar 7. Materi “Alat Penentuan Arah Kiblat”

\section{HASIL DAN PEMBAHASAN}

\section{Peletakan Dasar (Laying the Foundation)}

Kegiatan yang dilakukan pada tahap ini adalah mengkomunikasikan tentang $\mathrm{PkM}$ yang akan dilaksanakan kepada stakeholders yang ada di komunitas, yaitu Pimpinan Pusat Persatuan Islam (PERSIS), diantaranya adalah Ketua Umum, Bidang Pendidikan (Dr. H. Irfan Syafrudin, M.Ag) dan Ketua Hisab dan Rukyat (H. Muhammad Iqbal Santoso).

Hasil yang diperoleh dari diskusi dengan steakholder adalah menyetujui terlaksananya kegiatan PkM sebagai wujud kerjasama antara Lembaga Penelitian dan Pengabdian UIN Sunan Gunung Djati Bandung dan Pimpinan Pusat PERSIS. Pada tahapan ini juga disetujui adanya pembagian tugas baik dalam teknis pelaksanaan kegiatan, maupun pembagian tugas dalam penyampain materi pada acara pelatihan.

\section{Perencanaan (Research Planning)}

Pada tahapan ini dilakukan perencanaan penelitian, yaitu memperjelas isu penelitian dan tujuan penelitian yang akan dilakukan, mengkerucutkan sasaran penelitian dan mengidentifikasi efeknya untuk lembaga.

Penelitian dilakukan untuk mengukur tingkat kemampuan guru-guru dalam menyelesaikan masalah trigonometri dan masalah terkait penentuan arah kiblat. Dilakukan pre test sebelum pelaksanaan pelatihan dan post test sesudahnya. Selain, dibuat instrumen soal juga dibuat angket evaluasi untuk mengukur tingkat kepuasan dan kemanfaatan terhadap pelatihan.

\section{Pengumpulan dan analisis data (information gathering and analysis)}

Pengumpulan data dilakukan dengan melakukan test awal (pretest) kepada guru-guru yang mengikuti pelatihan, setelah pelatihan dilakukan juga test akhir (postest) untuk mengukur pengetahuan trigonometri dan pengetahuan tentang Ilmu Falak. Selain itu diberikan juga angket evaluasi untuk mengukur tingkat keberhasilan kegiatan Pengabdian kepada Masyarakat (PkM) yang dilakukan.

Analisis data menggunakan statistik deskriptif menggunakan software SPSS 25, dengan sampel diambil dari 34 orang guru yang bersedia mengisi pretest dan postest. Instrumen yang diberikan untuk mengukur tingkat pengetahuan guru-guru tentang 
trigonometri dasar dan konsep tentang penentuan arah kiblat. Dari hasil test diperoleh data yang tercantum pada tabel 1 sebagai berikut :

Tabel 1. Statistik Deskriptif

\begin{tabular}{llllll} 
& N & Minimum & Maximum & Mean & $\begin{array}{c}\text { Std. } \\
\text { Deviation }\end{array}$ \\
\hline Pretest & 34 & 2 & 9 & 6.94 & 1.632 \\
Postest & 34 & 6 & 10 & 8.21 & 1.343 \\
\hline
\end{tabular}

Pada tabel 1 terlihat bahwa pretest yang dilakukan kepada guru-guru MA PERSIS memiliki nilai rata-rata 6,94 . Setelah pelatihan nilai rata-rata menjadi meningkat dengan dilakukan postest. Nilai rata-rata postest adalah 8,21 .

Sedangkan instrumen angket yang diberikan kepada guru menunjukkan hampir $100 \%$ memberikan tanggapan positif terhadap keberlangsungan acara pelatihan. Berikut tabel 2 sebagai rangkuman tanggapan peserta berdasarkan angket yang disebar.

Tabel 2. Respon Peserta

\begin{tabular}{|c|c|c|}
\hline No & Pertanyaan & Rangkuman Respon \\
\hline 1 & $\begin{array}{l}\text { Pendapat tentang } \\
\text { Pelatihan }\end{array}$ & Bagus dan bermanfaat \\
\hline 2 & $\begin{array}{l}\text { Mengapa tertarik } \\
\text { terhadap } \\
\text { pelatihan }\end{array}$ & $\begin{array}{l}\text { Ingin mengetahui lebih dalam } \\
\text { matematika dalam ilmu } \\
\text { Falak. }\end{array}$ \\
\hline 3 & $\begin{array}{l}\text { Informasi yang } \\
\text { diperoleh }\end{array}$ & $\begin{array}{l}\text { Perhitungan arah kiblat } \\
\text { menggunakan trigonometri } \\
\text { segitiga bola. }\end{array}$ \\
\hline \multirow[t]{2}{*}{4} & $\begin{array}{l}\text { Harapan setelah } \\
\text { mengikuti acara }\end{array}$ & $\begin{array}{l}\text { - Dapat meningkatkan mutu } \\
\text { guru. } \\
\text { - Pendampingan pasca } \\
\text { pelatihan }\end{array}$ \\
\hline & & $\begin{array}{l}\text { Pelatihan diperluas untuk } \\
\text { bidang ilmu lain }\end{array}$ \\
\hline
\end{tabular}

\section{Aksi dan Temuan (information gathering and analysis)}

Guru-guru dalam pelatihan ini memperoleh wawasan bagaimana arah kiblat ditentukan secara matematis. Selain itu, guru-guru juga dibekali pengetahuan tentang dinamika ilmu Falak, sehingga mereka memahami kaitan erat ilmu Falak dengan bidang matematika. Dan terakhir juga dilaksanakan workshop untuk mengukur arah kiblat menggunakan alat Mizwala Qibla Finder, hal ini dilakukan untuk menambah hasanah keilmuan guru-guru terkait media yang bisa digunakan untuk mengukur arah kiblat.

Dari data yang berhasil dikumpulkan menunjukkan bahwa setelah pelatihan guru mengalami peningkatan pengetahuan berkaitan tentang konsep trigonometri dalam ilmu Falak. Hal ini ditenjukkan dengan meningkatnya nilai rata-rata postest. Dari hasil angket yang disebar juga menunjukkan respon positif guru setelah mengikuti pelatihan.

Harapan setelah acara pelatihan yang diselenggarakan sebagai bentuk Pengabdian kepada Masyarakat Dosen Pendidikan Matematika UIN Sunan Gunung Dajti Bandung ini adalah memberikan nilai manfaat untuk guru-guru dalam mengaplikasikan konsep-konsep matematika dalam ilmu Falak. Sehingga, pembelajaran matematika dapat terintegrasi dengan mata pelajaran lainnya.

\section{Ucapan Terima Kasih}

Penulis mengucapkan terima kasih kepada berbagai pihak yang telah membantu dalam penulisan makalah ini. Kegiatan ini didanai oleh Pusat Pengabdian LP2M UIN Sunan Gunung Djati Bandung tahun anggaran 2019.

\section{PENUTUP}

\section{Kesimpulan}

Kegiatan PkM yang bertujuan meningkatkan kemampuan pemahaman matematis guru-guru MA PERSIS dalam menyelesaikan masalah dalam ilmu Falak. Dari hasil kegiatan menunjukkan bahwa kegiatan ini dapat meningkatkan pemahaman matematis guru-guru.

\section{Saran}

Dapat dilaksanakan kembali kegiatan PkM yang mengaplikasikan ilmu matematika dalam Islam, seperti menentukan waktu shalat wajib, awal bulan hijriah, menentukan waktu terjadinya gerhana dll

\section{DAFTAR PUSTAKA}

Aji, Rizqon Halal Syah. 2014. "Khazanah Sains Dan Matematika Dalam Islam." Salam: Jurnal Filsafat dan Budaya Hukum 1(1): 155-68. 
Alimuddin, Alimuddin. 2016. "Sejarah Perkembangan Ilmu Falak." Al Daulah : Jurnal Hukum Pidana dan Ketatanegaraan 2(2): 18194.

Baki, Adnan. 1992. "Science History." Journal of Islamic Academy of Sciences 5(3): 225-28.

Fatwa, Fahmi, and Rosyadi Satria Hamdani. 2016. "Penerapan Model Contextual Teaching And Learning (CTL) Dalam Pembelajaran Ilmu Falak." AL-MURABBI: Jurnal Studi Kependidikan dan Keislaman 3(1): 55-69.

Hanafi, Mohammad dkk. 2015. Community Based Research. Surabaya: LP2M UIN Sunan Ampel Surabaya.

Huda, Mualimul, and Mutia. 2017. "Mengenal Matematika Dalam Perspektif Islam.” Jurnal Kajian Keislaman Dan Kemasyarakatan 2(2): 182-99.

Marpaung, Watni. 2015. Pengantar Ilmu Falak. Jakarta: Prenadamedia Group.

Muhtar, Fathurrahman. 2014. "Abu Abdullah Ibn Musa Al-Khawarizmi (Pelopor Matematika Dalam Islam)." Jurnal Beta 7(2): 82-97.

Muniri. 2016. "Kontribusi Matematika Dalam Konteks Fikih.” Ta'alum 04(02): 193-214.

Nashrullah, Nashih. 2014. "KH Ali Ghazaly Pakar Hisab Dari Persis.” Republika.co.id.

Syaripudin, Arip. 2007. "Korelasi Antara Kemampuan Pemahaman Trigonometri Dengan Pemahaman Ilmu Falak Pada Pokok Bahasan Penentuan Awal Waktu Shalat Fardhu: Penelitian Deskriptif Di Kelas XI Mualimin Pesantren Persatuan Islam 2 Bandung." UIN Sunan Gunung Djati Bandung.

Syukur. 2010. "Efektifitas Penggunaan Hisab Praktis Dalam Pembelajaran Ilmu Falak Di Ma Minat Kesugihan-Cilacap Tahun Ajaran 2009/2010.” 